\title{
Naisten perheväkivaltakäyttäytyminen
}

Perheväkivalta tai perheväkivallan tekijä tuo meille ehkä ensimmäiseksi mielikuvan miehestä tekijänä. Se on ymmärrettävää, koska näin se on yhteiskunnassamme määritelty ja kulttuurisesti ymmärretty. Esimerkiksi vuoden 2017 lopulla julkaistun Istanbulin sopimuksen toimeenpanosuunnitelman tavoitteena on torjua ja ennaltaehkäistä perheväkivaltaa, ja vähentää naisiin ja tyttöihin kohdistuvaa väkivaltaa. Sopimukseen on kirjattu näkyviin, että nainen on uhri, mutta tekijä on henkilö. Voimme ehkä kysyä miksi tekijästä on tehty sukupuoleton? Luonnollisesti toivon, että seuraavassa ohjelmassa tavoitteena olisi kaikkiin perheenjäseniin kohdistuvan perheväkivallan torjuminen ja ennaltaehkäisy. Naisten perheväkivaltakäyttäytymiseen puuttuminen voi suojata heitä tulevaisuudessa perheväkivallalta. Tutkimustulokset ovat jo vuosikymmeniä osoittaneet, että naiset käyttävät perheissä väkivaltaa yhtä paljon kuin miehet. Rikostilastojen mukaan miehet käyttävät lievää perheväkivaltaa Suomessa enemmän kuin naiset, mutta vakavaa perheväkivaltaa käyttävät miehet ja naiset suunnilleen yhtä paljon. Ymmärrämme varmasti, ettei rikostilastoissa ole koko totuus, koska kaikki teot eivät päädy poliisin tietoon. Vuonna 2014 naisiin kohdistuneen väkivallan kustannusten on Suomessa laskettu olleen 1,2 miljardin luokkaa. Tutkimusta tehdessäni mietin toistuvasti, mitkä ovat miesten kokeman parisuhdeväkivallan kustannukset. Toistuvasti mietin myös sitä, mikä olisi optimaalisin tapa mitata väkivallan kustannuksia. Minulla on vahva ymmärrys, että perheväkivaltakäyttäytymiseen liittyvät myös ylisukupolviset kokemukset ja seuraukset.

Läpi tutkimukseni tasapainoilin sen tietoisuuden kanssa, ettei tutkimusaiheeni mukaile perinteisiä sukupuoliroolikäsityksiä. Tutkimuksen naisia kuunnellessani kuitenkin vakuutuin, että heidän äänensä tulee saada kuuluviin. Perheväkivaltakäyttäytyminen tuottaa kärsimystä myös tekijälleen. Lienee aiheellista todeta, että suhtaudun naisten kokemaan perheväkivaltaan yhtä vakavasti kuin naisten tekemäänkin perheväkivaltaan. Ymmärrän, että globaalilla tasolla naisten kokema perheväkivalta priorisoidaan. Me voimme pohtia myös sitä, onko fyysisiä jälkiä jättävä perheväkivalta vakavampaa kuin vuosia jatkuva fyysisiä jälkiä jättämätön emotionaalinen perheväkivalta. Mielestäni kumpaankin väkivaltaan pitäisi suhtautua yhtä vakavasti. Tiedämme myös, että perheväkivalta usein eskaloituu eli lievä väkivalta raaistuu jatkuessaan. Tämä kokemus oli myös tutkimukseni naisilla. Väkivaltakult- tuurin tutkija Satu Lidmanin (2015) mukaan yhteiskunnassamme on käsitys, että naisilla on sanalliset keinot purkaa olojaan, mutta miehet purkavat olojaan tekoina. Tutkimukseni naisten kokemukset vahvistavat tätä käsitystä, mutta ovat ristiriidassa toiminnan kanssa.

Naisten perheväkivaltakäyttäytyminen on ollut sen tunnistamisesta asti vaikea aihe. Ensimmäisiä kertoja tutkijat pyrkivät osoittamaan naisten parisuhdeväkivaltakäyttäytymisen yhtäläistä esiintyvyyttä miesten parisuhdeväkivaltakäyttäytymisen kanssa jo 1970- ja 1980-luvuilla, mutta näitä tutkimustuloksia ei julkaistu. Jälkeenpäin syyksi on arveltu pelkoa siitä, että naisten väkivaltaisuuden osoittaminen olisi vienyt huomion heidän kokemastaan parisuhdeväkivallasta. Tuohon aikaan oli vallalla käsitys, että perheväkivalta liittyy patriarkaalisiin yhteiskuntarakenteisiin. Tämä tarkoittaa sitä, että miehen käyttämä parisuhdeväkivalta on osa hänellä perheessä olevaa sosiaalista ja taloudellista valtaa. Siihen liittyy myös ajatus, että avioliiton myötä nainen menettää itsenäisyyteensä sekä hallinnan oikeutuksensa ja muuttuu naisesta vaimoksi. Olemme kulkeneet tuosta ajasta melkein 40 vuotta eteenpäin ja suomalaisen hyvinvointiyhteiskunnan tavoite on olla tasa-arvoinen kaikkia sen kansalaisia 
kohtaan. Yhteiskuntarakenteita muokkaamalla on mahdollista hitaasti muokata myös yhteiskunnan kulttuuria, kuten on esimerkiksi naisten työssäkäynnin kohdalla tapahtunut.

Taide on ollut kautta aikain keino tuoda esiin yhteiskunnallisia epäkohtia ja tabuja. Lidman (2015) on kuvannut kirjassaan Väkivaltakulttuurin perintö esimerkkejä taiteesta 1500- ja 1600- luvuilta. Eräässä maalauksessa nainen antaa miehelle selkään. Väkivallan kohteena oleva mies on kuvattu narrina. Samalta ajalta on ruotsalainen näytelmä, jossa miestä kohtaan väkivaltaa käyttäneen naisen todetaan muuttuneen käyttäytymisensä seurauksena mieheksi. Viimeaikaisista naisten perheväkivaltakäyttäytymistä kuvaavista näytelmistä itseäni puhutteli Tampereen Teatterin näytelmä Huojuva Talo. Maaliskuussa silmiini osui Aamulehden sarjakuva B. Virtasesta. Voin todeta myös sen pyrkineen tekemään näkyväksi naisten perheväkivaltakäyttäytymiseen liittyviä asenteita. Sarjakuvassa vaimo kysyy B. Virtaselta hänen katsoessaan televisiota, että mitä hän niin tarkkaan katsoo. B. Virtanen vastaa, että televisiota. Vaimon vastaus on lyönti takaraivoon ja toteama kyllästyneisyydestä miehen viisasteluihin. Viimeisessä kuvassa B. Virtanen istuu nenä kiinni televisioruudussa todeten, että naarmuhan tuossa oli, tarkoittaen tv-ruutua. Sarjakuvassa toistuu jo vuosisatoja sitten kuvattu asetelma, jossa vahva nainen satuttaa hieman reppanaa miestä tai narria kuten se 1500-luvulla kuvattiin. Sarjakuvassa minua puhutteli myös se, ettei mies reagoi mitenkään lyöntiin.
Naisten käyttämä perheväkivalta kuitenkin satuttaa miehiä. Miehet eivät aina välttämättä tarvitse lääkärin apua fyysisten vammojen hoitamiseksi, mutta samalla tavalla heidän koskemattomuuteensa kajotaan ja sitä loukataan. Toisaalta sarjakuva kertoo erinomaisesti myös siitä, miten väkivalta usein perheissä syntyy. Ihmiset tulkitsevat toistensa sanomisia omien kokemustensa ja ennakko-oletustensa mukaisesti. Eivätkä he aina pysty kuulemaan toisen todellisia sanoja. Tämä ei liene sukupuolisidonnainen asia. Onkin ehdotettu, että perheväkivaltakäyttäytymistä voisi sukupuolen sijaan ennemmin tarkastella ihmisten persoonaan liittyvien ominaisuuksien avulla, mahdollinen aiempi traumatisoituminen tunnistaen.

Perheväkivalta ei ole vain puolisoiden välistä väkivaltaa. Se kohdistuu myös lapsiin, joko suoraan tai välillisesti. Välillinen väkivalta tarkoittaa, sitä että lapsi joutuu näkemään vanhempien välistä väkivaltaa. Onkin arvioitu, että lapset kokevat Suomessa eniten perheväkivaltaa. Olemme eläneet saman noin 40 vuotta aikaa, kun lapsiin kohdistuva kuritusväkivalta on ollut laissa kiellettyä. Asenteet kuritusta kohtaan ovat huomattavasti tiukentuneet. Edelleen on kuitenkin paljon perheitä, jotka pitävät kuritusväkivaltaa sopivana keinona puuttua lapsen sopimattomaan käytökseen.

Tutkimukseni naisten lapsiin kohdistunut perheväkivaltakäyttäytyminen ei ollut satuttanut lapsia fyysisesti vakavasti. Tutkimuksen naiset eivät olleet poikkeus suomalaisessa yhteiskunnassa, koska äidit käyttä- vät lapsia kohtaan enemmän väkivaltaa kuin isät. Korkeasti koulutetut naiset käyttävät enemmän verbaalista väkivaltaa lapsiaan kohtaan kuin matalasti koulutetut naiset. Tiedämme myös, että lapsuudessaan väkivaltaa kokeneet ihmiset käyttävät sitä todennäköisemmin aikuisuudessa kuin he, jotka sitä eivät ole kokeneet. Tätä kutsutaan ylisukupolviseksi väkivaltakäyttäytymisen siirtymiseksi.

\section{MITÄ YLISUKUPOLVISUUS ON?}

Ylisukupolvisuus on jotain, mikä siirtyy sukupolvelta toiselle. Sitä voisi kutsua myös perinnöksi. Tämän tutkimuksen kannalta keskeisiä ylisukupolvisia perintöjä väkivaltakäyttäytymisen lisäksi ovat esimerkiksi kiintymyssuhteet, koska kiintymyssuhteiden tiedetään siirtyvän sukupolvelta toiselle melko muuttumattomina. Kiintymyssuhde muodostuu lapsen ensimmäisten elinvuosien aikana vanhemman ja lapsen välisessä vuorovaikutuksessa. Turvallisessa vuorovaikutussuhteessa lapsi oppii, että aikuinen vastaa hänelle, kun hän tarvitsee vanhempaansa. Lapsi uskaltaa tarkastella ympäristöään, koska tietää vanhemman olevan läsnä, kun hän palaa tutkimusretkeltään. Turvattomasti kiintynyt lapsi on voinut joutua kokemaan epävarmuutta aikuisen läsnäolosta. Vaihtoehtoisesti vanhempi on voinut olla kykenemätön vastaamaan lapsen tarpeisiin ja tunteisiin. Turvallinen kiintymyssuhde on keskeinen lapsen mielenterveyden sekä emotionaalisen ja sosiaalisen kehityksen kannalta. Vaikka kiintymyssuhteen rakentuminen ajoittuu ihmisen ensimmäisiin elinvuosiin, se voi muokkaantua 
myös nuoruudessa ja aikuisuudessa. Tämä edellyttää kokemusten muuttumista ja muokkaantumista tärkeästä toisesta.

Ylisukupolviseen perheväkivaltakäyttäytymiseen liittyy myös ylisukupolvinen traumatisoituminen. Se tarkoittaa vanhempien traumaattisten kokemusten siirtymistä sukupolvelta toiselle. Tätä tarkoitin pohtiessani perheväkivaltakustannusten yhteiskunnallisia kuluja. Perheissä, joissa on ylisukupolvisia traumoja voi olla tunnistettavissa ilmiöitä, jotka liittyvät vanhempien traumatisoitumiseen. Se voi näyttäytyä perheen vuorovaikutuksessa esimerkiksi vaikenemisen muurina tai vanhemman ja lapsen roolien sekoittumisena. Roolien ollessa epäselvät voi lapsi toimia vanhemman hoivaajana. Tutkimuksen naisilla oli lukuisia kokemuksia äitiensä hoivaamisesta, kun äidit eivät olleet kyenneet turvalliseen vanhemmuuteen. Traumatisoituneilla vanhemmilla voi olla vaikeuksia olla emotionaalisesti läsnä lasten kanssa, tästä esimerkkinä vetäytyvä vanhemmuus. Vanhemmuudessa esiintyvät ongelmat sopivat usein myös emotionaalisen väkivallan tai laiminlyönnin määritelmiin, joita ovat verbaalinen uhkaaminen, loukkaaminen, lapsen käyttäytymisen kontrollointi tai lapseen kohdistuvat epäasialliset odotukset. Nämä odotukset voivat olla liiallisia lapsen ikään ja kehitysvaiheeseen suhteutettuna. Emotionaalista väkivaltaa on myös toisen liiallinen suojelu tai sosiaalisten suhteiden rajoittaminen. Se on myös toisen huomiotta jättämistä. Arviolta $30 \%$ ihmisistä kokee elämänsä aikana emotionaalisen väkival- taa tai laiminlyöntiä, usein kuitenkin lievämuotoista. Ihmisistä 10-15\% kokee sitä merkittäviä määriä. Emotionaalisen väkivallan tutkimuksen on osoitettu olevan haastavaa, koska ilmiö on monikerroksinen ja abstrakti.

Perheväkivalta on monimuotoista. Edellä kuvaamani emotionaalisen perheväkivallan lisäksi perheissä käytetään myös fyysistä väkivaltaa. Usein perheväkivallasta puhuttaessa ajatellaankin sen olevan fyysistä. Fyysinen väkivalta tarkoittaa toisen tarkoituksellista satuttamista. Se voi aiheuttaa murtuneita luita, mustelmia, palovammoja tai haavoja. Fyysisen väkivallan seuraukset voivat olla heti näkyviin tulevien vammojen lisäksi kauaskantoisia terveydellisiä haittoja. Yhteyksiä on voitu osoittaa esimerkiksi sydän- ja verisuonitautien, diabeteksen sekä lihavuuden ja koetun fyysisen perheväkivallan välillä. Perheväkivalta voi olla myös seksuaalista tai taloudellista väkivaltaa, mutta se voi olla myös lapsen laiminlyöntiä. Laiminlyöntiä on niin fyysinen kuin emotionaalinenkin lapsesta huolehtimattomuus. Fyysinen lapsen laiminlyönti tarkoittaa lapsen fyysisistä tarpeista kuten puhtaudesta, ravinnosta tai levosta huolehtimattomuutta.

Haluan muistuttaa, että lapsuuden traumatisoitumisen ei tarvitse tarkoittaa aina koettua väkivaltaa, vaikka edellä liitin lapsuuden traumatisoitumisen ja perheväkivallan yhteen ylisukupolvisuutta kuvatessani. Psykiatri Raisa Cacciatore kuvaa runossaan Perheväkivalta traumaattista menetystä, jolloin hän on jäänyt vaille toista vanhempaa ja miten siitä on seurannut tunteiden kätkemistä.
Kukaan ei opettanut minua elämään

Melkoinen harmi ja puute

Struktuuri puuttuu.

Menneisyys ja tulevaisuus

sekoittuvat mössöksi.

Elämä ei ole kaari ei jana

Vaan ristiin rastiin meneviä

betkiä

Kipu pysähdyttää tässä ja nyt

Naulitsee tämän hetken

Kipupisteeksi ristiin.

Niinpahaa

Olenko unohtanut olla kiltti

On vain tämä hetki.

Ja selviytyminen tässä ja nyt

Ilman luottamusta tulevaan.

Paras unohtaa

Mutta silti uskon,

Että lastensuojelu- ja

kirkollislaeissa

On aivan varmasti kohta, että

Äidit eivät saisi kuolla

Pitkäperjantaina vuonna 1962.

Paitsi että

Se on kirkollispyhän

väärinkäyttöä

Se on pahimman laatuista

Perheväkivaltaa.

Tulee liian paljon lapselle

unohdettavaa

Ja kilttinä olemista.

Tutkimukseni naisia ehdottomasti yhdistävä tekijä runon kanssa oli kilttinä oleminen. $\mathrm{He}$ olivat lapsena kokeneet itsensä kilteiksi ja pärjääviksi tytöiksi. Runon kuvauksessa tulee näkyviin myös traumatisoituneen ihmisen kokemus itsestään. Heillä on usein runsaasti itsesyytöksiä. Yksi tutkimukseni keskeinen käsite on minuus. Se tarkoittaa ihmisen käsitystä itsestään. Minuus muodostuu vuorovaikutuksessa toisten ihmisten kanssa. Ihmisen kyky tunnistaa tunteitaan liittyy minuuteen. Kaltoinkohtelua kokeneiden ihmisten on usein vaikeaa tunnistaa omia 
tunteitaan. Edellä kuvatun runon tapaan eräs tutkimukseni nainen totesi, että hänen oli kovin vaikea muistaa lapsuudestaan asioita ennen avun saamista. Hänen elämänsä ei ollut jana tai kaari, vaan se oli asioita ja välähdyksiä sieltä täältä. Hänen lapsuutensa oli ollut kovin traumaattinen. Lapsuuteen liittyi äidin mielenterveysongelma ja isän päihdeongelma. Hänelle kiltteys oli tarkoittanut yritystä olla hermostuttamatta vanhempiaan. Kiltteys oli toki auttanut häntä pärjäämään ja suorastaan menestymään elämässään. Kipua lapsuuden yksinäisyydestä ja peloista se ei ollut kuitenkaan vienyt pois. Kiltteys ei ollut liioin auttanut vanhempia parantumaan. Toinen tutkimuksen nainen kuvasi avun vaikutuksia heräävänä sisäisenä vapinana. Vapina oli aiemmin elämässä piilotettujen tunteiden heräämistä ja tuntemista.

Hoitotieteessä naisten perheväkivaltakäyttäytymistä ei ole aiemmin tutkittu. Perheväkivaltaa hoitotieteessä muutenkin melko vähän. Saamme toki hoitotyöhön paljon tietoa lääketieteestä, psykologiasta ja sosiaalitieteistä. Ilmiötä on aiheellista tutkia ja jo tutkittua tietoa soveltaa tieteenalallammekin lisää, jotta perheitä kohtaavat ammattilaiset voisivat paremmin tunnistaa ilmiön ja auttaa. Tutkimuksen naisetkin olivat hakeneet apua ensimmäiseksi terveydenhuollon ammattilaisilta. Ilmiön tunnistamisen ja ymmärtämisen tärkeys liittyy myös siihen, että perheväkivallan seuraukset näyttäytyvät somaattisen hoitotyön lisäksi myös mielenterveys- ja päihdetyössä. Mielenterveyshoitotyön ydintä on ihmisen itsetuntemuksen ja tunteiden sietämisen, minuuden tukeminen. Hoitotieteessä ei ole liioin tutkittu sitä miten kulttuuriset sukupuoliroolit vaikuttavat tapaamme kohdata ihmisiä. Tutkimuksellani haluan tuoda äänen naisten kokemuksille omasta perheväkivaltakäyttäytymisestään, koska perheväkivaltaa käyttävät naiset eivät voi hyvin. Heillä on oikeus tulla kuulluiksi ja näkyviksi, jotta avun saaminen helpottuu. Naisille henkilökohtaisella tasolla tutkimuksen merkitys on siinä, että heidän perheväkivaltakäyttäytymiseensä liittyvä häpeä helpottuu.

\section{PIA KeISKI}

Terveystieteiden tobtori

Yhteiskuntatieteiden tiedekunta

Lebtori, Tampereen

ammattikorkeakoulu

\section{KIRJOITUSKUTSU}

\section{SLA teemanumero: Ilmastokriisi}

Minkälaisia muutoksia ilmaston lämpeneminen tuo ihmisten hyvinvointiin, terveyteen tai vaikkapa sairauksien esiintyvyyteen? Minkälaisia ratkaisuja voisimme tehdä terveyden edistämisessä, terveyskäyttäytymisessä, sosiaali- ja terveydenhuollossa tai -politiikassa ilmastonmuutoksen hillitsemiseksi? Mitä ilmastonmuutos merkitsee globaalin terveyden näkökulmasta?

Sosiaalilääketieteellinen aikakauslehti julkaisee teemanumeron ilmaston lämpenemisestä ja sen merkityksestä sosiaalilääketieteelle. Kutsumme aihepiiristä kiinnostuneita tutkijoita ja tutkijaryhmiä kirjoittamaan teemanumeroon vertaisarvioitavia, empiirisiä tai teoreettisia, tutkimusartikkeleita tai puheenvuoroja.

Lähetä enintään 250 sanan abstrakti kirjoituksesta osoitteeseen editor@socialmedicine.fi viimeistään 28.2.2019. Teemanumeroon liittyvät mahdolliset kysymykset voi osoittaa myös samaan osoitteeseen.

Aiheesta järjestetään mahdollisesti myös Sosiaalilääketieteellisen yhdistyksen teemaseminaari vuonna 2019. 